\title{
Effect of Zinc and Iron Enriched Organic Manures on Growth and Yield of Rice under Sodic Soil Conditions
}

\author{
R. J. Sankavi ${ }^{1 *}$, S. Avudaithai ${ }^{1}$, S. Somasundaram ${ }^{2}$ and T. Sherene Jennita Rajammal ${ }^{3}$ \\ ${ }^{1}$ Department of Agronomy, Anbil Dharmalingam Agricultural College and Research Institute, \\ Tiruchirappalli, India \\ ${ }^{2}$ Cotton Research Station, Veppanthattai, Perambalur, India \\ ${ }^{3}$ National Pulses Research Centre, Vamban, Pudukottai, Tamil Nadu Agricultural University, \\ Tamil Nadu, India \\ *Corresponding author
}

\section{A B S T R A C T}

The field study was conducted at Anbil Dharmalingam Agricultural College and Research Institute, Thiruchirapalli during late samba season of 2019-2020 to evaluate the effect of

\section{Keywords}

Enriched organic manures, Zinc, Iron, Poultry manure, Vermicompost and FYM

\section{Article Info}

\section{Accepted:}

18 November 2020

Available Online:

10 December 2020 enriched organic manures with different levels of zinc and iron on growth and yield of rice under sodic soil condition. The experiment was laid out in randomized block design with three replications. Three levels of zinc and iron were enriched with three different organic manures. The treatments consisted of recommended dose of fertilizers with enriched poultry manure, vermicompost and farmyard manure each of $500 \mathrm{~kg}$ per hectare with $100 \% \mathrm{Zn} \& \mathrm{Fe}(37.5$ and $30 \mathrm{~kg} / \mathrm{ha}), 75 \% \mathrm{Zn} \& \mathrm{Fe}(28$ and $22 \mathrm{~kg} / \mathrm{ha})$ and $50 \% \mathrm{Zn} \mathrm{\&} \mathrm{Fe}$ $(18.7 \mathrm{~kg}$ and $15 \mathrm{~kg} / \mathrm{ha})$ and control i.e. Application of $\mathrm{Zn}(37.5 \mathrm{~kg} / \mathrm{ha})+\mathrm{Fe}(30 \mathrm{~kg} / \mathrm{ha})$ alone were taken. The enriched organic manures were applied at the time of transplanting of rice. The applied enriched organic manures showed significant impact on the growth and yield parameters of rice. Readings taken at harvest showed that the highest plant height $(159.01 \mathrm{~cm})$, number of tillers $\left(604 \mathrm{no} / \mathrm{m}^{2}\right)$, root length $(25.18 \mathrm{~cm})$, dry matter production $\left(12188 \mathrm{~kg} \mathrm{ha}^{-1}\right)$, panicles $/ \mathrm{m}^{2}\left(479 \mathrm{no} / \mathrm{m}^{2}\right)$, filled grain per panicle $\left(479 \mathrm{no} / \mathrm{m}^{2}\right)$, grain and straw yield (4535 kg ha $\mathrm{knd}^{-1} 259 \mathrm{~kg} \mathrm{ha}^{-1}$ ) were recorded with the application of poultry manure enriched with $100 \%$ zinc and iron along with recommend dose of fertilizers over control. This was on par with vermicompost enrichment with $100 \%$ zinc and iron. The lowest growth and yield parameters were observed with the control.

\section{Introduction}

Rice (Oryza sativa L.) encompasses all the aspect of livelihood and acts as the major staple food crops in the world as well as India, feeding $60 \%$ of the world population. It bestows $21 \%$ of human per capita energy and $15 \%$ of protein of human nutrient requirements (Depar et al., 2011). In India, nearly $43.7 \mathrm{~m}$ ha area is under rice cultivation and the production accounts to $112.7 \mathrm{~m} \mathrm{t}$ with an average productivity of $2.57 \mathrm{t} \mathrm{ha}^{-1}$. In Tamilnadu, it is grown in an area of $1.8 \mathrm{~m}$ ha with an annual production of $6.6 \mathrm{~m} \mathrm{t}$ and the average productivity is about $3.6 \mathrm{t} \mathrm{ha}^{-1}$ 
Among all abiotic stresses soil salinity is the acute one. Presence of high concentration of soluble salts, $\mathrm{Na}$ domination on cation exchange complex and low organic content of the soil are the main problem in saline and soidic soils (Newell and Nicole, 2013). Crops grown on these soils suffer from specific ionic toxicities $(\mathrm{Na}, \mathrm{Cl})$ and deficiencies $(\mathrm{Ca}, \mathrm{K}, \mathrm{Fe}$ and $\mathrm{Zn}$ ) causing substantial yield decline (Yadav et al., 2011).

Zinc play an important role in enzyme activation, protein synthesis, carbohydrate and lipids metabolism, auxins synthesis and chlorophyll biosynthesis which greatly influence the plant growth and yield (Graham et al., 2000; Mousavi, 2013).Iron is required to maintain proper metabolic and physiological processes in plants. The high soil $\mathrm{pH}$ and bicarbonate content reduces the solubility of iron and zinc in the soil solution and plants growing in alkaline soils often exhibit distinct symptoms of Fe deficiency (Kakei et al., 2012; Qadar, 2002).

Addition of organic amendments to soil, decrease the bulk density, pH, EC and ESP while it increase the CEC, water holding capacity and organic carbon content of the soil which have a diluting effect on alkali soil (Wang et al., 2014). Though $\mathrm{ZnSO}_{4}$ and $\mathrm{FeSO}_{4}$ are the widely used fertilizers for its solubility, low cost availability in the market, fixation of nutrients is the major problem in the sodic soil. In that case augumented methods like use of synthetic chelates can be endorsed to increase the insubstancial uptake of micronutrients. Beside using synthetic chelates like Zn-EDTA, Zn- DTPA and EDDHA-Fe which is costly, making use of organic manures that act as natural chelates for enrichment sounds to be economically viable. When the micronutrients are enriched with organic manure, organo complexes are formed. This prevents the nutrient fixation in soil and increase amount of available $\mathrm{Zn}$ and
$\mathrm{Fe}$ in the root zone of plants. The slow and steady release of micronutrients from the organic manures makes it available for plants for longer time which in turn increases the yield of the crop (Meena et al., 2006; Verma et al., 2001). The application of zinc-enriched poultry manure reduces $50 \%$ of $\mathrm{Zn}$ fertilizers (Latha et al., 2001). Iron-enriched vermicompost is a rich source of total and available iron. The present study investigates the effect of zinc and iron enriched organic manures on the growth and yield parameters of rice in sodic soil condition.

\section{Materials and Methods}

The research was carried out during late Samba of 2019- 2020 at Anbil Dharmalingam Agricultural College and Research Institute, Trichy, which geographically fall under the coordinates - $11^{\circ} 32^{\prime}$ North latitude, $78^{\circ} 83^{\prime}$ East longitude and $85 \mathrm{~m}$ above mean sea level. The composite soil sample was collected from the experimental field and it was analyzed for its physical and chemical properties. The soil was clayey loam in texture, moderately drained classified as Vetric Ustropept. The soil $\mathrm{pH}$ was 8.7 which was alkaline in nature, EC $0.75 \mathrm{ds} / \mathrm{m}$, having bulk density of $1.28 \mathrm{Mg} \mathrm{m}^{-3}$. The soil was low in organic carbon (0.42), low in available $\mathrm{N}$ (175. $16 \mathrm{~kg} / \mathrm{ha})$ medium in available $\mathrm{P}(16.8$ $\mathrm{kg} / \mathrm{ha})$ and high in available $\mathrm{K}(292.4 \mathrm{~kg} / \mathrm{ha})$.

The experiment was laid out in randomized block design with three replications using rice(TRY 3 variety) as a test crop. Ten treatment combinations was taken with recommended dose of fertilizers(150:50:50 NPK) and enriched organic manures with zinc and iron (farm yard manure, vermicompost and poultry manure). Since it was sodic soil extra $25 \%$ of $\mathrm{N}$ was applied along with RDF. The treatments consist of $\mathrm{T}_{1}-\mathrm{RDF}+\mathrm{Zn}(37.5$ $\mathrm{kg} / \mathrm{ha})+\mathrm{Fe}(30 \mathrm{~kg} / \mathrm{ha}), \mathrm{T}_{2}-\mathrm{RDF}+\mathrm{FYM}$ enriched with $100 \%$ zinc + iron, $\mathrm{T}_{3}-\mathrm{RDF}+$ 
vermicompost enriched with $100 \%$ zinc + iron, $\mathrm{T}_{4}-\mathrm{RDF}+$ Poultry manure enriched with $100 \%$ zinc + iron, $\mathrm{T}_{5}-\mathrm{RDF}+\mathrm{FYM}$ enriched with $75 \%$ zinc + iron, $\mathrm{T}_{6}-\mathrm{RDF}+$ vermicompost enriched with $75 \%$ zinc + iron, $\mathrm{T}_{7}-\mathrm{RDF}+$ Poultry manure enriched with $75 \%$ zinc + iron, $\mathrm{T}_{8}-\mathrm{RDF}+\mathrm{FYM}$ enriched with $50 \%$ zinc + iron, $\mathrm{T}_{9}-\mathrm{RDF}+$ vermicompost enriched with $50 \%$ zinc + iron, $\mathrm{T}_{10^{-}} \mathrm{RDF}+$ Poultry manure enriched with $50 \%$ zinc + iron. The organics viz., FYM, press mud, poultry manure and vermicompost each $500 \mathrm{~kg} / \mathrm{ha}$ were mixed with $100 \%$ (37.5kg/ha $\mathrm{Zn} \mathrm{\& 30} \mathrm{kg} \mathrm{/ha} \mathrm{Fe)}$ ,75\% (28 kg/ha Zn and $22 \mathrm{~kg} / \mathrm{ha} \mathrm{Fe})$ and $50 \%$ $(18.7 \mathrm{~kg} / \mathrm{ha} \mathrm{Zn}$ and $15 \mathrm{~kg} \mathrm{Fe})$. The enriched organics were aerobically incubated for 60 days and moisture content was maintained @ $60 \%$.

The growth parameters (plant height, number of tillers, root length and dry matter production) were recorded at different growth stages viz., tillering, panicle initiation, flowering and harvest. Yield parameters viz., number of panicles $/ \mathrm{m}^{2}$, number of grains per panicle, thousand grain weight, grain and straw yield were recorded at the harvest.

\section{Results and Discussion}

\section{Effect on growth parameters}

The application of enriched organic manures had significantly influenced the growth parameters (Table 1). At harvest the maximum plant height $(159.01 \mathrm{~cm})$, number of tillers $\left(604 \mathrm{no} / \mathrm{m}^{2}\right)$, root length $(25.18 \mathrm{~cm})$ and dry matter( $\left.12188 \mathrm{~kg} \mathrm{ha}^{-1}\right)$ were recorded with the application of enriched poultry manure with $100 \%$ zinc and iron $\left(\mathrm{T}_{4}\right)$ compared to the zinc and iron alone application. This was followed by treatment $\mathrm{T}_{3}$. With regard to plant height and dry matter production both the above mentioned treatments were on par with each other. The lowest plant height, number of tillers, root length and DMP were observed with the control.

When both micronutrients (zinc and iron) and organic manures were combined together for enrichment, organo complexes were formed due to the fact that under anerobic condition organic carbon present in the manures undergo chelation. This caused increased availability of available zinc and iron to the crops. Increased nutrition caused more branching which in turn increased the plant growth. The increase in plant height, dry matter and root length was owing to that zinc assists in the amino acid synthesis, auxin synthesis and iron catalyst to the formation of chlorophyll (Rout et al.,2012). This sharpen the photosynthetic activity, cell elongation and division. Thus enhanced the growth of the plant. Among all organic manures used in the study, poultry manure had more essential nutrients and enrichment of iron and zinc with poultry manure also increases the availability of $\mathrm{Zn}$ and $\mathrm{Fe}$ contents in the manures (Mansuri et al.,2019)

\section{Effect on yield parameters and yield}

The combination of treatments of enriched organic manures with zinc and iron had shown the impact on the yield and yield parameters of rice (Table 2). Significantly higher number of panicles $\left(479 \mathrm{no} / \mathrm{m}^{2}\right)$ and filled grains per panicle (204) were observed with the application of enriched poultry manure with $100 \%$ zinc and iron. This was on par with treatment $\mathrm{T}_{3}$.

The lowest values were observed with the treatment only having zinc and iron alone. The grain yield and straw yield ranges from $3309 \mathrm{~kg} \mathrm{ha}^{-1}$ to $4535 \mathrm{~kg} \mathrm{ha}^{-1}$ and $6328 \mathrm{~kg} \mathrm{ha}^{-1}$ to $7259 \mathrm{~kg} \mathrm{ha}^{-1}$. Significantly the highest grain and straw yield was recorded with the application of $\mathrm{T}_{4}\left(4420 \mathrm{~kg} \mathrm{ha}^{-1}\right.$ and $7258 \mathrm{~kg}$ $\mathrm{ha}^{-1}$ ) over all treatments. 
Table.1 Effect of zinc and iron enriched organic manures on growth parameters of rice at harvest stage

\begin{tabular}{|c|c|c|c|c|}
\hline Treatment & $\begin{array}{c}\text { Plant } \\
\text { height }(\mathbf{c m})\end{array}$ & $\begin{array}{l}\text { Number of } \\
\text { tillers } / \mathbf{m}^{2}\end{array}$ & Root length(cm) & $\begin{array}{c}\text { Dry matter } \\
\text { production }\left(\mathrm{kg} \mathrm{ha}^{-1}\right)\end{array}$ \\
\hline$T_{1}-100 \%$ RDF + Zn (37.5 kg /ha)+Fe (30 kg /ha) & 109.74 & 328 & 14.33 & 9777 \\
\hline$T_{2}-100 \%$ RDF + FYM enriched with $100 \% \mathrm{Zn}+\mathrm{Fe}$ & 142.15 & 460 & 19.60 & 11658 \\
\hline $\mathrm{T}_{3}-100 \% \mathrm{RDF}+\mathrm{VC}$ enriched with $100 \% \mathrm{Zn}+\mathrm{Fe}$ & 147.93 & 526 & 22.96 & 11881 \\
\hline $\mathrm{T}_{4}-100 \% \mathrm{RDF}+\mathrm{PM}$ enriched with $100 \% \mathrm{Zn}+\mathrm{Fe}$ & 159.01 & 604 & 25.18 & 12188 \\
\hline$T_{5}-100 \%$ RDF + FYM enriched with $75 \mathrm{Zn}+\mathrm{Fe}$ & 134.92 & 409 & 16.97 & 10796 \\
\hline $\mathrm{T}_{6}-100 \% \mathrm{RDF}+\mathrm{VC}$ enriched with $75 \% \mathrm{Zn}+\mathrm{Fe}$ & 140.01 & 441 & 17.86 & 10998 \\
\hline $\mathrm{T}_{7}-100 \% \mathrm{RDF}+\mathrm{PM}$ enriched with $75 \% \mathrm{Zn}+\mathrm{Fe}$ & 142.37 & 497 & 18.83 & 11209 \\
\hline $\mathrm{T}_{8}-100 \% \mathrm{RDF}+\mathrm{FYM}$ enriched with $50 \% \mathrm{Zn}+\mathrm{Fe}$ & 125.72 & 408 & 14.93 & 10248 \\
\hline $\mathrm{T}_{9}-100 \% \mathrm{RDF}+\mathrm{VC}$ enriched with $50 \% \mathrm{Zn}+\mathrm{Fe}$ & 128.02 & 388 & 16.01 & 10401 \\
\hline $\mathrm{T}_{10^{-}} 100 \% \mathrm{RDF}+\mathrm{PM}$ enriched with $50 \% \mathrm{Zn}+\mathrm{Fe}$ & 131.78 & 369 & 16.98 & 10549 \\
\hline SEd & 7.89 & 30.70 & 1.05 & 366.90 \\
\hline $\mathrm{CD}(\mathbf{P}=\mathbf{0 . 0 5})$ & 16.57 & 64.51 & 2.21 & 770.83 \\
\hline
\end{tabular}

FYM- Farm yard manure VC - Vermicompost PM - Poultry manure

Table.2 Effect of zinc and iron enriched organic manures Yield and yield parameters of rice

\begin{tabular}{|c|c|c|c|c|}
\hline Treatment & $\begin{array}{c}\text { No of } \\
\text { panicles/ } \mathbf{m}^{2}\end{array}$ & $\begin{array}{c}\text { Filled grain per } \\
\text { panicle }\end{array}$ & $\begin{array}{l}\text { Grain yield } \\
\left(\mathrm{kg} \mathrm{ha}^{-1}\right)\end{array}$ & $\begin{array}{c}\text { Straw yield } \\
\left(\mathrm{kg} \mathrm{ha}^{-1}\right)\end{array}$ \\
\hline$T_{1}-100 \%$ RDF + Zn (37.5 kg /ha)+ Fe (30 kg /ha) & 245 & 125 & 3309 & 6328 \\
\hline$T_{2}-100 \%$ RDF + FYM enriched with $100 \% \mathrm{Zn}+\mathrm{Fe}$ & 421 & 181 & 4252 & 7023 \\
\hline $\mathrm{T}_{3}-100 \% \mathrm{RDF}+\mathrm{VC}$ enriched with $100 \% \mathrm{Zn}+\mathrm{Fe}$ & 468 & 196 & 4365 & 7121 \\
\hline $\mathrm{T}_{4}-100 \% \mathrm{RDF}+\mathrm{PM}$ enriched with $100 \% \mathrm{Zn}+\mathrm{Fe}$ & 479 & 204 & 4535 & 7259 \\
\hline $\mathrm{T}_{5}-100 \% \mathrm{RDF}+\mathrm{FYM}$ enriched with $75 \mathrm{Zn}+\mathrm{Fe}$ & 360 & 170 & 3808 & 6702 \\
\hline $\mathrm{T}_{6}-100 \% \mathrm{RDF}+\mathrm{VC}$ enriched with $75 \% \mathrm{Zn}+\mathrm{Fe}$ & 393 & 175 & 3938 & 6770 \\
\hline $\mathrm{T}_{7}-100 \% \mathrm{RDF}+\mathrm{PM}$ enriched with $75 \% \mathrm{Zn}+\mathrm{Fe}$ & 422 & 182 & 4057 & 6853 \\
\hline $\mathrm{T}_{8}-100 \% \mathrm{RDF}+\mathrm{FYM}$ enriched with $50 \% \mathrm{Zn}+\mathrm{Fe}$ & 277 & 145 & 3498 & 6495 \\
\hline $\mathrm{T}_{9}-100 \% \mathrm{RDF}+\mathrm{VC}$ enriched with $50 \% \mathrm{Zn}+\mathrm{Fe}$ & 308 & 154 & 3632 & 6500 \\
\hline $\mathrm{T}_{10^{-}} 100 \% \mathrm{RDF}+\mathrm{PM}$ enriched with $50 \% \mathrm{Zn}+\mathrm{Fe}$ & 329 & 159 & 3751 & 6527 \\
\hline SEd & 13.27 & 7.03 & 140 & 184 \\
\hline $\mathrm{CD}(\mathbf{P}=\mathbf{0 . 0 5})$ & 27.89 & 14.77 & 294 & 386 \\
\hline
\end{tabular}

FYM- Farm yard manure VC - Vermicompost PM - Poultry manure

This grain yield increase was upto $30 \%$ when compared to straight application of iron and zinc application. This was on par $\mathrm{T}_{3}$ and $\mathrm{T}_{2}$. The lowest grain and straw yield were recorded with the control. The increase in yield and yield components was due to increased zinc and iron availability through enriched organic manures. Maskina and Randhawa (1983) stated that the application of organic manures decrease the soil $\mathrm{pH}$ and increase the $\mathrm{Zn}$ and $\mathrm{Fe}$ availability through formation of $\mathrm{Zn}$ and Fe chelates. The increased supply increases the use efficiency of $\mathrm{Zn}$ and Fe (Verma et al., 2001). The slow and steady release of nutrients by organic manure make the nutrients available to crop over long period of time there by increase in plant growth and yield (Meena et al., 2006). The enhanced grain and straw yield might also be due to increased availability of zinc which causes the biosynthesis of IAA and its part in the initiation of primordia of reproductive parts and assimilate partitioning towards them, causes increase in flowering and fruiting which in turn tap more yield (Rathod et al.,2012; Mansuri et al.,2019) 
From the given study, it is concluded that application of enriched poultry manure with $37.5 \mathrm{~kg} / \mathrm{ha} \mathrm{Zn} \& 30 \mathrm{~kg} / \mathrm{ha} \mathrm{Fe}$ along with recommended dose of fertilizers increase the growth and yield parameters of rice under sodic soil condition.

\section{References}

Mansuri, S. A., Shakhela, R. R., and Jat, K. N. P. J. 2019. Effect of different zinc enriched organics on nutrient content and uptake by summer pearl millet [Pennisetum glaucum L.] on loamy sand. Journal of Pharmacognosy and Phytochemistry, 8(1): 724-730.

Qadar, A. 2002. Selecting rice genotypes tolerant to zinc deficiency and sodicity stresses. I. Differences in zinc, iron, manganese, copper, phosphorus concentrations, and phosphorus/zinc ratio in their leaves. Journal of plant nutrition, 25(3): 457-473.

Graham, R. D., Welch, R. M., and Bouis, H. E. 2001. Addressing micronutrient malnutrition through enhancing the nutritional quality of staple foods: principles, perspectives and knowledge gaps.

Wang, L., Sun, X., Li, S., Zhang, T., Zhang, W., and Zhai, P. 2014. Application of organic amendments to a coastal saline soil in north China: effects on soil physical and chemical properties and tree growth. PloS one, 9(2):e89185.

Yadav, S., Irfan, M., Ahmad, A., and Hayat, S. 2011. Causes of salinity and plant manifestations to salt stress: a review. Journal of Environmental Biology, 32(5): 667.

Mousavi, S. R. 2011. Zinc in crop production and interaction with phosphorus.
Australian Journal of Basic and Applied Sciences, 5(9):1503-1509.

Rathod, D. D., Meena, M. C., and Patel, K. P. 2012. Evaluation of different zincenriched organics as source of zinc under wheat-maize (fodder) cropping sequence on zinc-deficient Typic Haplustepts. Journal of the Indian Society of Soil Science, 60(1):50-55.

Newell, N. (2013). Effects of soil salinity on plant growth. Plant Physiology.

Depar, N., Rajpar, I., Memon, M. Y., and Imtiaz, M. 2011. Mineral nutrient densities in some domestic and exotic rice genotypes. Pakistan Journal of Agriculture: Agricultural Engineering Veterinary Sciences (Pakistan).

Rout, G. R., and Sahoo, S. 2015. Role of iron in plant growth and metabolism. Reviews in Agricultural Science, 3: 1-24.

Maskina, M. S., and Randhawa, N. S. 1983. Effect of organic manures and zinc levels on the availability of zinc, iron, manganese and copper to wetland rice. Indian Journal of Agricultural Sciences.

Kakei, Y., Ishimaru, Y., Kobayashi, T., Yamakawa, T., Nakanishi, H., and Nishizawa, N. K. 2012. OsYSL16 plays a role in the allocation of iron. Plant molecular biology, 79(6): 583-594.

Meena, M. C., Patel, K. P., and Rathod, D. D. 2006. Effect of $\mathrm{Zn}$ and Fe enriched FYM on mustard yield and micronutrient availability in loamy sand soil (Typic Haplustept) of Anand. Journal of the Indian society of soil Science, 54(4): 495-499.

Verma, C. P., Tripathi, H. N., and Prasad, K. 2001. Effect of FYM and zinc sulphate on yield and yield attributes of rice grown after paddy nursery. Crop Research-Hisar-, 21(3):382-383.

\section{How to cite this article:}

Sankavi, R. J., S. Avudaithai, S. Somasundaram and Sherene Jennita Rajammal, T. 2020. Effect of Zinc and Iron Enriched Organic Manures on Growth and Yield of Rice under Sodic Soil Conditions. Int.J.Curr.Microbiol.App.Sci. 9(12): 2670-2674.

doi: https://doi.org/10.20546/ijcmas.2020.912.316 